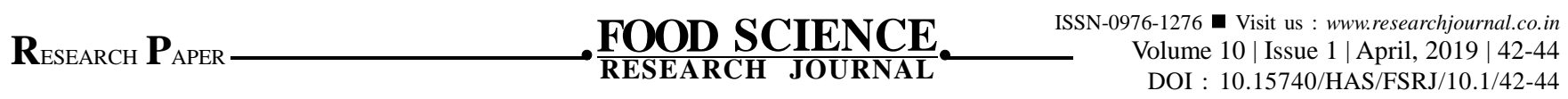

\title{
Formulation of pasta incorporated from linseed flour
}

\author{
Pragya Mishra and Suman Devi
}

Pasta was prepared from whole wheat flour, linseed flour and spinach powder (WWF:LF:SP). Linseed flour was incorporated at three percent level viz., 10,15 and 20 per cent. Spinach powder content was constant i.e. at 5 per cent sensory evaluation of pasta prepared was done using nine point hedonic scale. Nutritional evaluation of pasta included estimation of moisture, crude protein, crude fibre crude fat, carbohydrate, fat, iron, calcium of pasta in the range of 10.83 per cent, 11.84 per cent, $6.80,4.80,63.53$ per cent, $2.20,10.76 \mathrm{mg}, 135 \mathrm{mg}$ by AOAC (1995) and Ranganna (2003). The result of study was revealed that 6.20 mean score of the 20 per cent linseed flour pasta. Breakfast cereal pasta have found $3 \mathrm{mg}$ iron and $30 \mathrm{mg}$ calcium in one serving bowl to fulfil the requirement of school going children according to the RDA whereas linseed rich pasta beneficial to health and combat the malnutrition.

Key Words : Pasta incorporated, Linseed flour

How to cite this article : Mishra, Pragya and Devi, Suman (2019). Formulation of pasta incorporated from linseed flour. Food Sci. Res. J., 10(1): 42-44, DOI : 10.15740/HAS/FSRJ/10.1/42-44. Copyright@ 2019: Hind Agri-Horticultural Society.

\footnotetext{
Author for correspondence :

Pragya Mishra, Department of Food and Nutrition, College of Home Science, C.S.A. University of Agriculture and Technology, Kanpur (U.P.) India

(Email : pragyavasumishra@gmail.com)

Associate Authors' :

Suman Devi, Department of Food and Nutrition, College of Home Science, C.S.A. University of Agriculture and Technology, Kanpur (U.P.) India
} 